\title{
Tuvalden tuşa: Sanat pazarındaki dijital dönüşümde NFT'lerin rolü
}

\author{
From canvas to key: The role of NFTs in the digital transformation of \\ the art market
}

${ }^{1}$ Dr. Öğr. Üyesi, Kütahya Dumlupınar Üniversitesi, Kütahya, Türkiye, emine.saygin@dpu.edu.tr

ORCID: 0000-0001-8435-2924

2 Dr., Eskişehir, Türkiye, seldakiygi@hotmail.com

ORCID: 0000-0002-4341-3249

Sorumlu Yazar/Corresponding Author:

Emine Pınar Saygın,

Kütahya Dumlupınar Üniversitesi,

Kütahya, Türkiye,

emine.saygin@dpu.edu.tr

Başvuru/Submitted: 4/09/2021

Revizyon/Revised: 5/11/2021

Kabul/Accepted: 26/11/2021

Yayın/Online Published: 25/12/2021

Atıf/Citation: Saygin, E.P., \& Findıklı, S. Tuvalden tuşa: Sanat pazarındaki dijital dönüsüumde NFT'lerin rolü, bmij (2021) 9 (4): 1452-1466, doi

https://doi.org/10.15295/bmij.v9i4.1930

\author{
Emine Pınar Saygın ${ }^{1}$ \\ Selda Findıklı
}

Öz

Bu çalışmada, pazarlama ve sanat buluşmasının uzun yıllara dayanan birlikteliğinin zaman içindeki dönüşümü ele alınmaktadır. Makalede sanat gibi estetiğin ve öznelliğin ön planda olduğu bir alanda dijitalleşmenin sanatla ilgili pazarları ve buradaki dinamikleri alııı ve satıcı açısından nasıl etkilediği NFT'ler aracılığıyla açıklanmaya çalışılmaktadır. Güncel dijital dönüşüm sürecinin bir parçası olan NFT teknolojisiyle sanat piyasasında eserin değeri ve sahipliği konuları ön plana çıkmaktadır. Teknolojik bilgi sermayesinin sanal ekonomiyi ve kripto tabanlı pazarları şekillendirdiği dijital ortamlardan sanat pazarları da payını almıştır. Bu pay sanat pazarlarındaki demokratikleşmeyi ve pazarlamanın ana eksenini oluşturan taraflarına değer katan yönü oldukça güçlü vurgulamaktadır. Satıcı konumunda olan sanatçılar, NFT'ler sayesinde aracısız olarak hem kazançlarını arttırdıkları hem de telif hakları ile ilgili önemli kazanımlar elde etmektedirler. Alıcılar ise sahipliklerini sadece şifre aracılığıyla bir anlamda aracısız ortamlarda "dijital mülkiyet sertifikaları" ile sonsuzluğa taşımaktadırlar. Sanat ve pazarlama birlikteliğinin dijitalleşme yönündeki birleşimlerinin sanat pazarlamasına nasıl yansıdığı kavramsal bir temelle literatüre kazandırılarak bu yeni oluşum için dayanak hazırlamak çalışmanın amacını oluşturmaktadır. Veri toplanmadığı ve kavramsal bir çalışma olduğu için ilgili kaynaklar taranarak NFT'nin sanat pazarlamasına uyarlanması bir akış, içerisinde açıklanmaya çalışılmıştır.

Anahtar Kelimeler: Sanat Pazarlaması, Dijital Pazarlama, NFT (Non-Fungible Token)

Jel Kodları: M30, M31, Z11

\begin{abstract}
This study discusses the transformation of the long-term coexistence of marketing and art meeting over time. In the article, how digitalization affects art-related markets and the dynamics therein in terms of buyers and sellers, in an area like art where aesthetics and subjectivity are at the forefront, are tried to be explained through NFTs. With NFT technology, which is a part of the current digital transformation process, the value and ownership of the work come to the fore in the art market. Art markets have also taken their share from the digital environments where technological knowledge capital has shaped the virtual economy and crypto-based markets. This share strongly emphasizes the democratization in art markets and the aspect that adds value to the central axis of marketing. Thanks to NFTs, artists in the position of dealers both increase their earnings and gain significant gains in copyrights. On the other hand, buyers carry their ownership to eternity with "digital property certificates" in a way without intermediaries, only using a password. The study aims to prepare a basis for this new formation by bringing to the literature how the combination of art and marketing in digitalization is reflected in art marketing with a conceptual basis. Since data was not collected and it is an abstract study, the adaptation of NFT to art marketing was tried to be explained in a flow by scanning the relevant sources.
\end{abstract}

Keywords: Art Marketing, Digital Marketing, NFT (Non-Fungible Token)

Jel Codes: M30, M31, Z11 


\section{Extended Abstract}

From canvas to key: The role of NFTs in the digital transformation of the art market

\section{Literature}

\section{Research subject}

The marketplace concept has existed throughout history and has taken different forms. With the increase in digitalization, this concept has gained another dimension. From the point of view of art marketing, firstly, online sales of concrete works came to the fore, and then the inclusion of digitally born works in the market came to the fore. This new marketplace and the means of exchange brought by it have also entered the focus of marketing. At this point, the remarkable privilege of NFTs, which serve for the dematerialization of abstract digital products, in terms of "digital ownership", intersects with liquid modernity. In other words, NFTs are for consumers of the digital world; It is a new way of appreciating intelligence, knowledge, technology and art with resources in the digital world.

Research purpose and importance

Explaining how digital infrastructures affect marketplaces with the advancement of technology through art markets forms the basis of the research. Rather than marketing for art, revealing the marketing components (value, possession, etc.) in art with the concept of NFT expresses the importance of the research.

Contribution of the article to the literature

This study aims to reveal the role of NFTs in digital transformation in the art market.

\section{Design and method}

Compilation research was carried out using the literature review method.

\section{Results of the article}

The versatility of interaction, expressed in postmodern marketing, is also experienced in art markets. Some vendors change, disguise (pseudonyms) and do not adapt their art to customer expectations, and there are customers with technological knowledge capital. The experience economy, where technical knowledge and intelligence is presented, is experienced in virtual environments. In the system where the digital foundations of the buyer and seller balances are laid with the NFT system, the exchange of marketing turns into environments in which "passwords" are the tool. In a sense, artificial intermediaries (cyphers) can be seen as new actors of "marketplaces". The NFT system can be interpreted as a robust system in which the desire to possess, but the gains after possession are more equitable.

\section{Suggestions based on results}

Quantitative and qualitative studies can be increased with artists related to the operation of the NFT system.

\section{Limitations of the article}

The fact that NFT is a new concept in art marketing constitutes the limitation of the study. 


\section{Giriş}

Sanat soyut bir zevk ve sübjektif bir bakış açısıdır. Ayrıca bir hedef kitlesi, o hedef kitlesine ulaşma kanalı ve somut bir ekonomik karşlığı vardır. Dijitalleşen dünyada bu somut karşıllık dönüşüm geçirmektedir. Pek çok alanı etkileyen sanallaşma sanat eserleri ve onların pazarlanma sürecini de etkilemektedir. Sanat eserleri ve takipçileri, özellikle de Covid-19 salgını ile birlikte daha fazla çevirim içi yaşanmaya başlanılan şu zamanlarda sanal galerilere, çevrimiçi müzayedelere isınmışken, şimdi bir yeniliğe daha adapte olmaları beklenmektedir. İngilizce adıyla (N)on-(F)ungible (T)okens diye adlandırılan NFT "yeri doldurulamaz jetonlar" anlamina gelmektedir. NFT'ler dijital sanat eserlerini ve koleksiyon ürünlerini tescil edilebilir ve satılabilir varlıklar haline getiren dijital sertifikalardır. NFT'ler de aynı sanat eserleri gibi tek ve eşsizdir, değiştirilemez, yeri doldurulamazlar, dünyada hiçbir NFT bir diğeri ile birebir ayn olamaz.

Tarih boyunca pazar yeri kavramı var olmuş farklı şekillere bürünmüştür. Dijitalleşmenin artmasıyla bu kavram başka bir boyut kazanmıştır. Sanat pazarlaması açısından bakıldığında önce somut eserlerin çevrimiçi satışlarının yapılması öne çıkmış sonrasında dijital ortamda doğmuş eserlerin pazarda yer alışı gündeme gelmiştir. Bu yeni pazar yeri ve onun getirdiği mübadele aracı pazarlamanın da odağına girmiştir. Örneğin, Şahin ve Söylemez'in (2021) dijital medya platformları üzerine ele almış oldukları çalışmada da belirttiği gibi dijital pazar yerlerinin artan önemi bu kapsamda değerlendirilebilir.

Pazarlama yıllar itibariyle önemli değer değişimlerinin gerçekleştiği sanat piyasası ile ilgilenmiş, sanat pazarlaması başlığında önemli çalışmalar gerçekleştirmiştir. Sanat pazarlaması literatürü ve bilgisi pazarlama ve sanat arasındaki ilişkiyi açıklamakta zaman zaman yetersiz kalabilmektedir. Bunu çözmek için kavramsallaştırmayı geliştirmek ve daha etkili pazarlama stratejileri oluşturmak gerekmektedir (Butler 2000:345). Özellikle dijitalleşmenin yükseldiği bu çă̆da yeni kavramlarında literatüre girmesi ile bu ihtiyaç artmaktadır. Bu makale dijital sanat pazarındaki NFT'ler ve değişen pazar yeri unsurlarını açıklamaya yönelik kavramsal bir çalışma niteliğindedir. Uzun bir geçmişe dayanan sanat ve pazarlama birlikteliğinin dijitalleşme yönündeki birleşimlerinin sanat pazarlamasına nasıl yansıdığının kavramsal bir temelle literatüre kazandırılarak yeni olan bu oluşum için dayanak hazırlamak çalışmanın amacını oluşturmaktadır.

\section{Literatür}

\section{Akışkan modernite}

Bauman'ın (2011) tarifiyle ilgilenilen alanların, takip edilen akımların değiştiği durağan olamayan "akışkan dünya" da şaşırmaya devam etmekteyiz. Akışkan modernite, kişilerin etkinlikleri ve uzun dönemli tasarılarındaki sosyal yapıların referans çerçeveleri olarak sunulamadığ çağdaş modernite zamanın ifade etmektedir (Bauman, 2007a:1) Bu kavram diğer bir ifadeyle standart kalıpları boşa çıkaran toplumsal yaşamdaki hızı, değişimi ve akışkanlığı içinde barındırmaktadır. Sosyal ayırımların katı olmadığı, zenginliğin ifşa edilmesinin statünün temeli olmadığı ortaya konulmaktadır. En önemlisi giderek artan statü belirteçlerinin sahiplik temelli değil, kaydileştirilmiş olması durumudur. Tüm bunlara ek olarak, işle veya kişisel gelişim projeleriyle ilişkili olan tüketim deneyimleri, önemli statü belirleyicileri olarak görülmektedir. Özellikle teknoloji odaklı alt kültürler arasında deneyimler ve seyahatler nihai statü sembolleri öncüleri arasındadır. Bu alt kültürde, statü göstergesi olarak zenginlik kullanılmazdır veya bununla gösteriş yapılamamaktadır. Para, sadece kişisel gelişim ve yaratıcı bilgi konuları için kullanıldığında anlamını bulmaktadır. Bunun sebebi vurgunun zekâ ve teknoloji konusunda bilgili olma hususunda yoğunlaşmasıdır. Tüm bu bağlamlarıyla değer verilen ve çağdaş lükse yansıyan lezzetler, esnek, dikkat çeken ve sahiplenilmeyene yönelik olanın işaretini yansıtmaktadır (Eckhardt ve Bardhi, 2020:87-95). Bu akışkanlıktan payını alan sanat ve sanatçı için de pazarlamanın dinamikleri değişmiştir. Sanatçı için sanatsal alan "modernist olmanın endişesinden uzak, alıntılanabilen ve kullanılacak birçok araçla dolu manipüle edilebilen verilerin sergilenmesini içermektedir (Bourriaud,2004:29). İşte tam da bu noktada soyut dijital ürünlerin kaydileşmesine hizmet eden NFT'lerin "dijital sahiplikler" hususundaki dikkat çeken ayrıcalığı akışkan modernite ile kesişmektedir. Başka bir ifadeyle NFT'ler, dijital dünyanın tüketicileri için; zekayı, bilgiyi, teknolojiyi, sanatı dijital dünyadaki kaynaklar ile yeni takdir etme biçimidir.

\section{Sanat pazarlaması tanımı}

Pazarlamanın sosyal bilim yönünü vurgulayan önemli tanımlardan biri "taraflarına değer yaratan değişim ilişkileri ağlarını inceleyen uygulamalı sosyal bir bilim" ifadesidir (Erdoğan, 2009:47). Değer değişimin olduğu tüm alanlarda pazarlama yer almaktadır. Ortaya bir ürünün çıkartıldığı ve bu ürünün izleyen gözlere bir değer olarak sunulduğu sanat eserleri de pazarlamanın konusuna girmektedir. Beğeninin somut bir karşılı̆̆ı olarak eserlerin satın alınması sanat pazarının oluşmasını sağlamıştır. 
Sanat ve para arasındaki ilişki çeşitli disiplinlerce sıklıkla sorgulanmıştır. Sanat piyasasında yer alanların iki farklı hayatı vardır. Bunlar; işlerinin devamını sağlamak için pazarlanabilir olduğunu düşündüğü eserleri bulmaya gayret ettiği kapitalist hayatı ile yaratıcılık ve anlamlardan oluşan sanatsal hayatıdır. Sanat mantığı sembolik, yaratıcı ve anlamlı yapıtların yaratılmasını temel alan nitel bir mantık iken, ticaretin mantığı metalaştırma ve sayısallaştırma üzerine kurulu nicel bir mantıktır (Velthuis, 2005:23-24).

"Pazar"; mekânsal bir alandaki değişim ilişkileri ağlarının şekillendirildiği, "Sanat pazarı"; değişim ilişkisindeki değerin "sanat" olarak ortaya konulduğu pazar ve "Tüketim ise"; yaşam tarzı ve kimlik oluşturma süreçlerindeki simgesel süreçler olarak ifade edilmektedir (Baudrillard, 2003:23; Aktaran: Çildir ve Fettahoğlu, 2019:50). Sanat yapıtını bir daha aynısının yapılamayacağının sonucu olarak eşsizliği ve bunun getirdiği tek olması hali değerini belirleyen önemli kriterlerdir. Bu eşsiz veya biricik olma durumu sanat yapıtının kıymetli olmasını sağlamaktadır (Thompson, 2011:1001) Bu nokta NFT'lerle anlam birliği açısından kesişmektedir. NFT'ler de bir sanat eseri gibi tek ve eşsizliğe sahiptirler.

1970'lerde pazarlama sanat için bir anlamda teknikleri birleştirmek olarak görülmüştür. Pazarlamacılar müşteriler ve sanatçılar arasındaki ortadaki kişi(aracı) olarak sanat organizasyonlarında hem satış biletlerini hem de kitleleri arttırmak için görevlendirilmişlerdir. Pazar araştırması, reklam ve promosyonlar gibi teknikler denenmiştir. 80'lere gelindiğinde ise pazarlama karar verme süreçlerinde etkili bir yol olmuştur. Bu yaklaşım pazarlamanın "felsefe" rolüne önem verilmeye başlanılan sanat pazarlaması oluşumunu başlatmıştır. 1990'lı yıllardan sonra ise sanat bağlamında sadece sanatlar için pazarlamanın kullanımından ziyade "sanat pazarlaması" tanımlanma eğilimine gidilmiştir. Bu durum bir organizasyon için pazarlamanın "yönlendirici felsefe" olarak rolüne dikkat çekmektedir (Lee, 2005:5-7). Bu bağlamda sanat pazarlaması, pazarlamanın en önemli dinamiği olan müşterilerin temel ihtiyaçlarını ve beklentilerini ayrıca değerlerini kavrayarak müzeler ve galerilerle işbirliği içerisinde uygun pazarlama iletişimi mesajları oluşturarak karar verme sürecini şekillendirmektedir (Slater, 2007:151).

\section{Sanat ve pazarlama ilişkisinin tarihsel süreci}

1879 yılında tarih öncesine ait ilk mağara resimlerinin bulunmasından bu yana Güney Fransa'daki Ardeche nehri üzerindeki Pont Arc'in yakınlarında bulunan Chauvet mağarasının 1995 yılındaki keşfiyle mağara resimlerinin günümüzden 32.000 yll öncesine ait olduğu tespit edilmiştir. Chauvet mağarasındaki çizimlerin mağara sanatının başlamasından itibaren ortaya koyduğu sorular sanat ve pazarlama birlikteliği için de ayrı önemlidir. Bu resimler kimler için çizilmişti? Hangi amaç için çizilmişlerdi? Mağaraların ziyaretçileri kimlerdi? (McGregor, 2021:20-23) Mağara resimleri için pazarlama yansımaları bu sorulara ilişkin cevaplarda saklıysa da tarihsel süreçte sanat eserlerinin ticari anlamda değer kazanmasının 17. yüzyıl Hollanda'sında gerçekleştirildiği ifade edilmektedir. Bu oluşumda tüccarların, sergilerin ve müzayedelerin sanat ortamını oluşturan unsurlar olduğu belirtilmektedir. 18. yüzyılda ise sanat aristokrat ve kentsoylu kesimler arasında yaygınlaştığı yer Fransa olmuştur. Sanat eserlerinin oluşturduğu talep sanatta aracıları kaçınılmaz kılmıştır. Fransız İhtilalinin sonucunda ekonomik gücü olan herkesin resim satın alma gücünü elde etmesi sanatta demokratik bir ortam oluşmasını sağlamıştır. 18. yüzyılda sadece Fransa değil Londra'da aracıları, sergileri, müzayede evleri ve koleksiyonerleri ile önemli bir sanat pazarı olarak ifade edilmektedir. 19. yüzyıl sanayi devriminin getirdiği değişimle bireyselliğin ön plana çıkarak sanattaki üslup ve üretim ortamının da değiştiği bir dönem olarak vurgulanmaktadır. 20. yüzyılın geç dönemlerinin getirdiği teknolojik gelişmeler ise sanatsal yaratıcılığın çok güçlü ve belki de en önemli dinamiğini oluşturmaktadır (Bozoğlu Demirdöven ve Ödekan, 2008:58).

Sanat tarihindeki sanatsal ortamlarda sanat eserlerini alıp satan kişileri oluşturan sanat pazarları aracıları pazarlama faaliyetleri için önemli bir örnek teşkil etmektedir. Vincent Van Gogh'un erkek kardeşi Theo Van Gogh gibi ünlü isimlerin de aralarında olduğu bu kişiler sanatçıların eserlerini maddi gücü yüksek kişilere veya koleksiyonculara tanıtıp satmışlardır. Bunun yanında diğer önemli bir pazarlama unsuru olarak sponsorluk kavramı tarihteki ünlü ailelerin (Medici ve Sforza vb.) sanatçılara verdikleri desteklerinde karşılık bulmaktadır (Beteş 2016:10).

Sanat ve kültüre olan ilginin yeniden canlanmasında ve kültür sosyolojisi, kültür ekonomisi ve sanat pazarlaması gibi yeni disiplin odaklarının ortaya çıkmasının önemli bir rolü bulunmaktadır (Kerrigan O'Reilly ve vom Lehn, 2009:203).

Teknolojik gelişmelerin hızıyla sanatın, sanatçının, izleyicinin ve sanat mekânlarının tanımlarının ve hatta algılanış biçimlerinin dönüştüğü görülmektedir. Sanatta yeni formlar sanatçıyı aynı anda tüketen, kullanan, üreten bir insan haline dönüştürmüştür (Çalıkoğlu, 2005:14). Teknolojik gelişmeler ve dijital 
ilerleme ile pazar yerleri ve pazarlama araçları da dönüşüm geçirmektedir. Bu dönüşüm sanat ve pazarlama buluşmasını da farklılaştırmakta ve sınırların daha da iç içe girmesini sağlamaktadır. Sanatçılar sanal dünyanın kendilerine sunduklarından faydalanarak çalışmalarının tanıtımını ve satışlarını kendileri gerçekleştirebilmektedirler. Ticaret ve sanatın birbirlerine zıt olmadıkları aksine sanat ekonomisinin finans kapitalinin ekonomisini yakından yansıttı̆̆ belirtilmektedir (Stallabrass, 2020:49). Bu nokta sanatın dijital platformlardaki yerinin varlığı ve gelişiminde, NFT' lerin öne çıkmasının arka planını da ortaya koymaktadır. Sanattaki pazar yerinin dönüşümünde, NFT yansımaları bu açılardan değerli görülmektedir.

\section{Sanattaki pazaryeri değişimi}

Pazar yeri, sanat eseri ve karşıllı̆ında mübadele edilebilecek olan değerin karşılaştığı yer ve andan ibarettir. Bu pazarlarda sanatla ilişki emtia, hizmet ve sanat eserleri ticareti yapılmaktadır. Sanat toplumdan izole değildir ve toplumun politik ve sosyo kültürel bağlamına dayanır. Sanat pazarlamasının yolculuğu 60'larda sanat yönetimi olarak Amerika Birleşik Devletleri'nde akademik bir disiplin olarak ortaya çıkması ile başlamıştır. Daha sonra ülkenin ekonomik gücü ile sanat arasındaki farkı ortadan kaldırmak için kültürel bir strateji olarak iş dünyası ve devlet, sanat dünyasını desteklemiştir (Lee ve Lee, 2017:2-11). Pazarlama, ürün kadar pazarların nasıl üretileceği, çeşitlendirileceği konularını da odağına almaktadır (Cemalcılar, 1965:72). Pazarlama literatürü açısından bu süreç "Pazarlamanın Genişleyen Ekseni” adlı ünlü makaleyle bağdaşmaktadır. Makalede, ürünler, mal, hizmet, kişi, örgüt ve fikir olarak tanımlanmış ve sınıflandırılmıştır. Genişleyen pazarlama kavramı fikir pazarlaması, kişi pazarlaması ve toplumsal pazarlama gibi değişik pazarlama uygulamaların ortaya koymuştur (Kotler ve Levy, 1969:10). Buna göre alıcı ve satıcılar, sadece uyaran ve uyaranlara cevap veren pasif aktörler değildir. Pazarlamanın değişen yeni literatüründe alıcı ile satıcı arasında var olan ortak anlamlara bağlı doğası gereği sosyal bir faaliyet olarak görülmeye başlayan pazarlar için pazardaki karmaşık ilişkiler diziler, ağlar veya sistemler vurgulanmıştır (Bagozzi, 1978:536).

Sanat açısından pazar yeri sanat eserlerinin alım satımının yapıldığı, el değiştirdiği ve parasal değerinin oluşturulduğu yerlerdir. Pazarlamanın genişleyen alanında kendine yer bulan sanat için pazar ortamları farklı seviyelerde açıklanmıştır. Organize olmamış bireysel sanatçılar için bir anlamda ilkel olarak nitelendirilen sanat pazarları; galeriler, yerel sanat fuarları ve sergileri, küçük satıcılar ve özel alıcılardan oluşan merkezi olmayan bir pazar olarak tanımlanmıştır. Bir üst seviye olan pazarlar ise sanatın ticaretinin yapıldığı New York, Londra, Paris ve Sdyney gibi önemli şehirler olmuştur. Pazar ortamlarının en üst seviyesi ise uluslararası yapıdaki sanatçıların oluşturduğu yerler olarak belirtilmiştir (Throsby, 1994:5). Normalde sanat eserlerinin piyasaları sürekli piyasalar değillerdir. Müzayedelerin belli zamanları vardır ve eserler tahvil, hisse senedi gibi standart değerlendirme tekniklerine tâbi değillerdir. Sanat piyasaları daha küçük ve giriş bariyerleri yüksek ve asimetrik bilginin hâkim olduğu piyasalardır (Cebrailoğlu, 2009:245). Küreselleşme ve dijitalleşme ile bu durum değişmiştir. Özellikle 90'lardan sonra teknolojinin huzlıca ilerlemesi ile değişen alanlardan biri de tüketicilerin sanat eserlerini satın almak için dijital platformları kullanmasına yönelik olmuştur. Bu platformlar sanat tüketicisinin ve satıcısının pazar yerinin dönüşümünü güçlü yaşadıkları pazarlar olarak yorumlanabilir. 2025'te sadece ABD'deki sanal sanat piyasası hacminin 2,39 milyar dolara çıkacağı tahmin edilmektedir. Çevrimiçi (online) müzayedelerin sağladığı şeffaflığın alıcılarda oluşturduğu güvenin bu artışta önemli olduğu belirtilmektedir (Hexaresearch, 2021). Bu artış aynı zamanda sanat pazarındaki hem inanılmaz fırsatların olduğu hem de değişken bir ekonomik alt yapının varlığı olarak da yorumlanabilmektedir. Gelişen teknoloji ile sanat konsepti ve bağlantılı kavramları genişlemiş bununla birlikte birçok yeni konu ve kavram gündeme gelmiştir. Küreselleşme özellikle çevrimiçi sanat pazarındaki büyüme ile birlikte sahiplik, fikri mülkiyet ve vergilendirme ile ilgili sorunlarda önemle üzerinde durulması gerekli konular haline dönüşmektedir (Çildir ve Fettahoğlu 2019:59).

Çalışmanın konusunu oluşturan NFT'ler dijital sahipliğin altının çizildiği, sanatın estetik kaygıdan yoksun yaşandığı sanatçının da uluslararası tanınırlığı ya da başarısı yanı sıra ekonomik kazanç elde ettiği ortamlara ışık tutmaktadır.

Küreselleşme ve dijitalleşme ile sanat piyasasında artan çevrimiçi satışlar sanat pazarının gelişmesi ve dönüşmesine neden olmuştur. Günümüzde sanatın dağıtımı (sanatçıdan ilk tüketiciye) ve el değiştirmesi (tüketiciler arasında yeniden dağıtım) farklı biçimlerde gerçekleşmektedir. Sanat pazarında dağıtım sistemlerinin genişlemesinde ve işleyişinin hızlanmasında, sanatçıların sistem içinde kabul görme çabaları ve internetin sağladığı olanaklar önemli etkilerdir (Bayrak 2013:125). Bu gelişmeler sayesinde sanat belli dağıtım kanallarının tekelinden çıkmış, herhangi bir sanatçıya herhangi dijital platformdan istediği alıcıya ulaşma imkânı vermiştir. 


\section{NFT tanımı}

Non Fungible Token'ın kısaltması olan NFT'lerin iyice anlaşılması için fungible ve olumsuzu olan nonfungible kelimelerinin etimolojisini açıklamak önemlidir. Fungible kelimesi Latince gerçekleştirmek "perform" kökünden türemiş ve ilk olarak 1649 yılında kullanılmıştır. Geniş kullanımında "değişebilir", "değiştirebilir" veya akışkan ya da her türlü şekle girilebilir tanımlarını da karşılamaktadır. Örnek olarak petrol ve yağ verilmiştir (Merriam-webster, 2021). Non-fungible kelimesi ise fungible kelimesinin olumsuzudur. Bir mal veya varlığın benzer mal ya da varlıklarla değiştirilememesidir.

Türkçe için farklı içeriklerde farklı çevirileri bulunmaktadır. Bir çevirisi "Gayrı-Misli Jeton" olarak yapılmıştır. Misli ürün yerine yenisinin konulabileceğini ifade etmektedir. Örneğin evimizde olan bir kilo unun bitmesi sonucu yerine "değer" bakımından aynı olan un alınabilir. Ama evimizdeki ünlü bir ressamın eşsiz tablosu ise bunun kaybı sonucu aynısının yerine konulması mümkün değildir. Aynısının yerine konulamayan ürünlere misli (eş, benzer) olmayan anlamında "gayri-misli" denmektedir (Evrimagaci, 2021). Başka bir yerde de Türkçe çevirisi olarak "değişimi mümkün olmayan para ya da çip "olarak karşılık bulmaktadır (Webrazzi, 2021). Bir diğer karşılığı olarak İngilizce sözlükteki karşılığını bulan "değiştirilemez token" olarak açılanmaktadır (Tr.cointelegraph, 2021). "Eşsiz token" olan çevirisinde blockchain üzerinde benzersiz bir varlığ gösteren kriptografik bir token ürün olarak ifade edilmektedir (Academy.binance, 2021). Çevirilerdeki anlamlar ufak farklar içerse de NFT'lerin ortak noktaları; eşsiz olmaları, değiştirilemez, yeri doldurulamaz olmaları ve sahibine mülkiyet hakkı sağlamalarıdır.

Pazarlamanın sağladığı en temel faydalardan birisi; mülkiyet faydasıdır. Üreticilerden tüketicilere mülkiyetlerin devrine mülkiyet faydası denir (Cemalcılar 1965:70). Alıcılar için önemli konulardan birisi ekonomik olarak karşıllı̆ını ödedikleri bir ürünün sahipliğinin taraflarına geçmesi beklentisidir. Sanat eserlerinin somut olarak üretildikleri ve somut olarak alıcılarına ulaştıııldıkları noktada mülkiyet açısından her şey çok nettir. Oysa üretimi bile soyut olarak gerçekleşen dijital eserlerde durum biraz daha karışık olmaktadır. Sanatta yaratıcığın emekten ziyade fikir ile gerçekleştiğini ifade eden Marcel Duchamp gibi pek çok sanatçı ve sanatsever somut olandan soyut olana geçişi uzun süreden beri kabul etmektedir (MacFarlane, 2015: 9) Dijitalleşme ile sanatın üretim şekli çıktısı mecrası bile soyutlaşmış çevrim içi hale gelmiştir. Bu durum yeni bir eksikliği ortaya çıkarmıştır. Eserlerin sahipliği nasıl olacak ve mülkiyet hangi aracı ile sağlanacaktır. Bu noktadaki boşluğu NFT kavramı doldurmaktadır.

\section{NFT'lerin özellikleri ve çalışma sistemi}

Ethereum, Bitcoin'den sonra ikinci gelen kripto birimidir. Kendine özgü zincir geliştirme kapasitesi bitcoinden farklılığına yol açarak kullanıcının amacına göre (oy kullanmak, taraftar tokenları gibi) serbest kullanımını sağlamaktadır (Fındıklı, 2021:8). 2013 yılında Rus asıllı Kanadalı bilgisayar programcısı Vitalik Buterin, ağda depolanan herhangi bir varlığı programlamak için herkes tarafından kullanılabilecek yerleşik bir Turing-bütünlüğü (Turing-complete) programlama diline sahip bir blok zinciri öneren Ethereum tanıtım belgesini yayınlamıştır. Yürütülen bu koda "akıllı sözleşme" tanımı verilmiş ve birçok merkezi olmayan uygulamanın geliştirilmesine yol açmıştır (Musan, William ve Gervais, 2020:15). Bu bağlamda Non-Fungible Token (NFT) Ethereum'um akıllı sözleşmeleriyle oluşturulan bir tür kripto para birimidir (Liv d., 2021: 1) NFT üretimi için en popüler blok zinciri Etherum'dan başka Binance Smart Chain, Polkadot, Flow by Dapper Labs Tron ve Tezos gibi blok zincirleri de vardır (Rfrnce.io, 2021).

Bir NFT'nin başlangıcını bir dijital varlı̆̆ın sahipliğinin genellikle bir ethereum ağında bir blok zincirine kaydettirmesi oluşturmaktadır. Bu dijital varlık sonraki aşamada sahiplik değişikliği ve blok zincirinde kayıtlı olan kripto para cinsinin ödemesi ile satılabilmektedir. Kripto para birimleri aracılığıyla işlem gören NFT'ler kripto para birimlerinden farklı özelliklere sahiptirler. NFT'ler saf varlıklar olarak tasarlanmışken kripto para birimlerinin önceliği para birimi olmalarıdır. Değiştirilebilir ya da takas edilebilir olma genel olarak kripto paralarının ve paranın temel özelliklerinden biridir. NFT'ler için ise değer verilen en temel varlık özelliği değiştirilemez oluşlarıdır (Dowling, 2021:1).

Benzersiz olan değişimleri mümkün olmayan NFT'ler birkaç farklı türde görülmektedir. İlk akla gelen türleri basında yer alan bazı yüksek satış fiyatları dolayısıyla dijital sanat ve koleksiyon olarak alınan ürünler (Sanat eserleri, futbol kartları vb.) olarak düşünülebilir. Dijital art veya koleksiyonerliğin formları görüntüler, videolar, grafik değiştirme biçimi (GIF, otomatik olarak tekrar eden kısa videoları oluşturmak için kullanılan belirli bir dosya biçimi), sesler, üç boyutlu sinema, mimari gibi içerikler, kitap, mesaj, şiir ya da kısa hikayeleri kapsamaktadır. Bunların dışında video oyunları, dijital ticari kartlar, dijital emlakçılık, alan adları (.com, net vb.) biletler ve tweetler NFT haline getirilebilir ve blok 
zincirler üzerinde yaratılabilir (mint) (Fortnow ve Terry, 2021: 17-32). Tüm bu biçimler koleksiyonerlik, metaverse (kurgusal evren), kullanılabilirlik, sanat, spor, oyun oynarak elde edilen kazanç (Game Fi) gibi alt başlıklarda toplanabilir ve dijital ortamdaki çoğu şeyin NFT'sinin üretilebilirliğini ortaya koyabilir (Kiong, 2021: 28). Çalışmanın konusu olan dijital sanat eserler de bunlardan biridir. Token haline getirilen NFT'ler kripto para kullanılarak satın alınabilir, diğer NFT'lerle değiştirilebilir veya ikinci el satışları yapılabilir (Rfrnce.io, 2021)

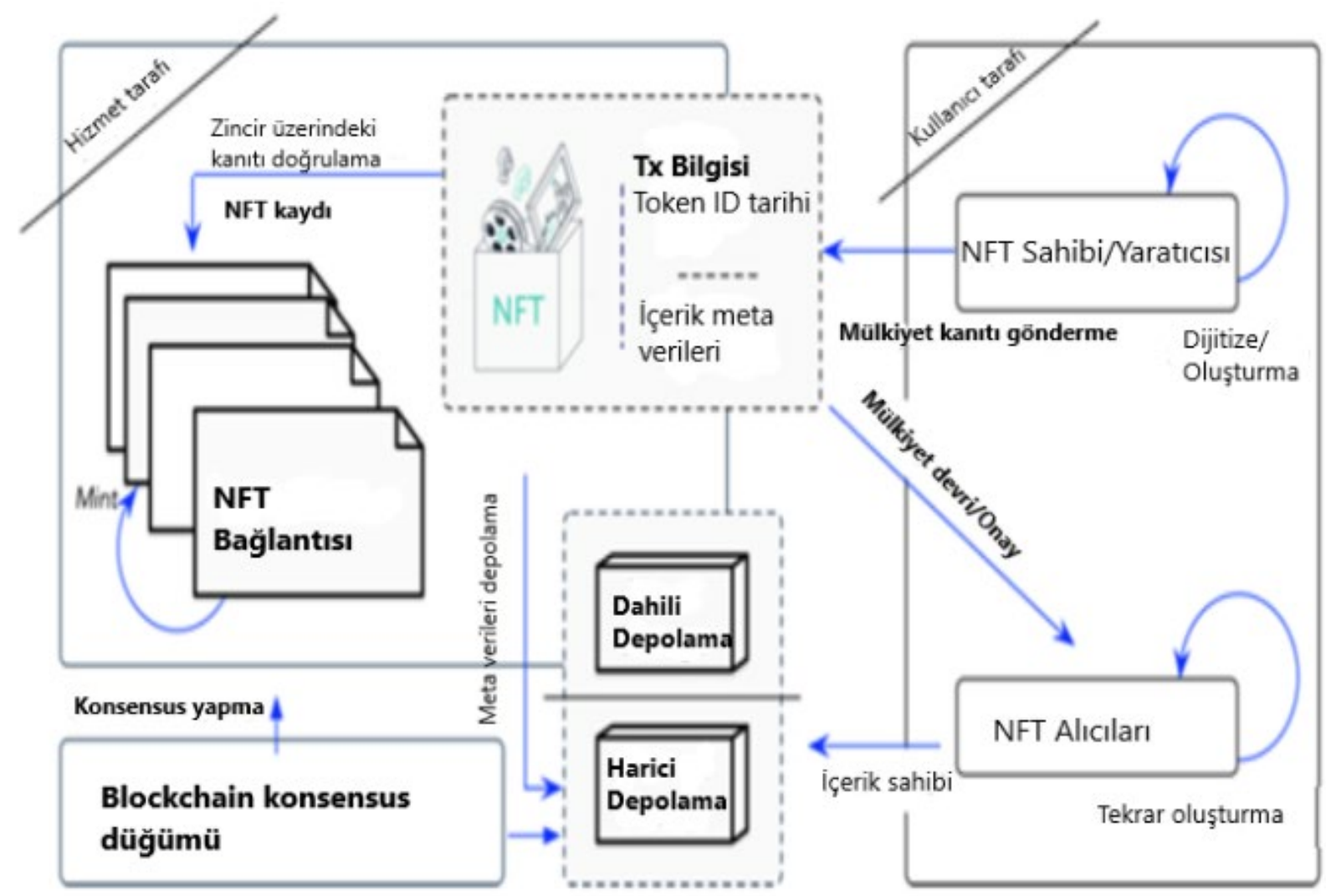

Şekil 1: NFT'lerin Çalışma Sistemi

Kaynak: Wang vd., 2021, s. 6

Şekil 1'de kullanıcı ve sunucu tarafından NFT'lerin nasıl çalıştığına dair sistem aşağıdaki gibi özetlenebilir;

NFT Digitize (NFT Sayılaştırılması): NFT sahibi dosyayı, başlığını ve tanımların (açıklamaların) tamamen doğruluğunu kontrol eder. Daha sonra ham verileri uygun bir şekilde sayılaştırır (Wang vd., 2021:5-6).

NFT Store (NFT Mağazası): NFT sahibinin ham verileri blok zincirinin dışında sakladığı veri tabanıdır (Wang vd., 2021:5-6).

NFT Sign (NFT İşareti): NFT sahipleri NFT'nin hash algoritması da dahil olmak üzere bir işlemi imzalar ve sonra akıllı sözleşmeye dönmesi için işlemi yeniden gönderir. Hash oranı hem bir blok üretmenin zorluk derecesini de belirler hem de Bitcoin ağının anlık işlemci gücünü gösteren bir ölçme sistemi olarak tanımlanmaktadır (Barimeks, 2021). Türkçe çevirisiyle düğümler (Node) bir ağ üzerinden iletişim kurarlar ve merkezi bir otoriteye dayanmadan blok zincirini işbirlikçi olarak oluştururlar. Blok zincirini oluşturan kayıtlar, zincire güç sağlayan düğümler tarafından yürütülen dağıtılmış bir protokol aracılığıyla yığınlar veya bloklar halinde blok zincirine eklenir. Her blok, mevcut tüm blokları sabitleyen ve tüm zincir geçmişinin güvenli bir sunumunu her bloğa yerleştiren önceki bloğun bir kriptografik karmasını içerir. Tüm düğümler, blok zincirine eklenecek bilgileri doğruladığından blok zincirinin bir bütün olarak doğru çalıştığı için tüm düğümlerin güvenini teşvik eder (Cachin ve Vukolic, 2017:4).

NFT Mint ve Trade (NFT yaratımı ve ticareti): NFT'yi blokzincirinin bir parçasına dönüştürmek anlamına gelen mint etmek token yaratımı ya da basımı olarak da ifade edilmektedir (Rfrnce.io, 2021).

NFT Confirm (NFT Onayı): İşlemin onaylanmasından sonra para basma işlemi tamamlanmaktadır. Bunun neticesinde de NFT'ler kalıcı kantları olarak sonsuza kadar benzersiz bir blok zinciri adresine bağlanırlar (Wang vd., 2021: 5-6). Başka bir açıklamayla sosyal medya hesabına fotoğraf yükler gibi 
yaratılan eser platforma yüklenmekte sonra platform bu eserin NFT'ye dönüştürülüp dönüştürülmeyeceğini sorgulamaktadır. NFT'ye dönüştürülen eser için kullanıcının cüzdanınızdan gaz ücreti kesilmekte ve işlem tamamlanmış olmaktadır (Koinbülteni, 2021).

Burada belirtilmesi gereken bir konu da Ethereum (ETH) ağındaki işlem ücretlerinin gaz ücretleri veya sadece gaz tüketimi olarak adlandırılmasıdır. Belirli bir işlem için gereken gaz miktarı iki ana faktöre bağlı olarak gereçekleşmektedir. İlk olarak, gaz işlemin türüne bağlı olmaktadır Daha açık bir ifadeyle gaz ücreti, işlemi gerçekleştirmek için gereken hesaplama gücü miktarına dayanmaktadır. ETH, başka bir token veya bir NFT gibi bir cüzdandan diğerine basit bir kripto para transferi ise, gaz ücreti daha düşük olmaktadır. Ağa uzun bir akıllı sözleşme dağıtılması durumunda ise gaz ücreti önemli ölçüde daha yükselmektedir. Gaz ücretini etkileyen ikinci faktör ise şebeke hacmidir. Hacim ne kadar yüksekse o kadar fazla talep yaratılmakta ve bu da gazın fiyatını yükseltmektedir. NFT'lere artan ilgi nedeniyle, Ethereum ağındaki işlemlerin sayısı, Ethereum'un popülaritesi ve fiyatı ile birlikte artmaktadır (Fortnow ve Terry, 2021: 75).

Tüm bu açıklamaların temelinde Ethereum blok zincirinde için NFT satın almak ve yaratmak (mint) için kullanımı kolay olan "MetaMask veya Trust Wallet" gibi ERC-721'i (Tabanı Ethereum olan token) destekleyen bir Ethereum cüzdanı gerekmektedir. Dijital cüzdanda da Ethereum blok zincirinin coini olan ETH (Ether) bulundurulması gerekmektedir. Dijital cüzdana erişim için de özel anahtar kelimelerden oluşan "seed phrase" verilmektedir (Rfrnce.io, 2021).

\section{NFT pazar yerleri}

Son yıllarda hem endüstriyel hem de bilimsel topluluklarda NFT'ler gözle görülür bir önemdedir. 2020 Aralık ayındaki NFT satış bedeli yaklaşık 12 milyon iken sadece iki ayda Şubat 2021'de 340 milyona ulaşmıştır. Kısa sürede gerçekleşen bu inanılmaz artış NFT'lerdeki çılgınlığı da başlatmıştır. NFT Ethereum'daki ilk NFT'lerden biri CryptoPunks'dır. 2017'de piyasaya çıkarılan ilk resmi olarak duyurulan NFT ise CryptoKitties'dir. Katılımcılar üreme mekaniğinin oyunlaştırılmasıyla yaratılan nadir kedileri müzayedeye çıkarmak için yüksek fiyatlarla güçlü bir şekilde rekabet etmişlerdir. Bir diğer örnek ise ünlü basketbol takımı NBA'da yaşanılan anların dijital kısa videolarını almak/satmak için oluşturulan NFT ticaret platformu olan NBA Top Shot'tır. Bu platformda dünyanın çeşitli yerlerindeki yüzlerce NBA taraftarı ve yükselen yıldız oyuncularından oluşan bir kadro oluşturularak 7 milyondan fazla oyundaki en iyi şut alanlarını toplamıştır. NFT'ler koleksiyonerlerin ve oyunların yanı sıra sanatsal faaliyetlerin (biletleme, değer, nesnelerin interneti) gelişimini de teşvik etmektedir (Wang vd., 2021:2).

NFT tokenlar ile alıcıları buluşturan platformlar olan NFT pazaryerlerinin gün geçtikçe daha da büyüyeceği beklenmektedir (Koinbülten, 2021). DappRadar verilerine göre, en büyük 5 NFT platformu Opensea, Axie Infinity, CryptoPunk, SuperRare.co ve Rarible olarak belirtilmektedir. Bu platformlar aşağıda kısaca açıklanmıştır. (DappRadar, 2021).

\section{Opensea}

Website adresi; Opensea.io'dur. NFT Pazar yerleri içinde en büyük ve en popüler olanıdır. NFT'lerin yaratılması, satılması ve alınması da kullanıcılara kolaylık sağlamaktadır (Fortnow ve Terry, 2021: 108). 2017'de kurulmuş olan platformu kullanıcıları Metamask, Bitski, Walletlink gibi cüzdanlarla kaydolarak kullanabilmekte ve çeşitli sanat eserlerinin, koleksiyon parçalarının NFT'lerini satabilmektedirler. Sanat dışında domain adları, sanal dünyalar, dijital kartlar, koleksiyonlar ve spor gibi birçok çeşitli alanda NFT tokenlar bulunur (Koinbülteni, 2021). DappRadar Hacmi 12,96 milyon olarak belirtilmektedir (DappRadar, 2021).

\section{Axie infinity}

DappRadar Hacmi 26,48 milyon dolardır. Axie Infinity, Axie adlı fantastik yaratıkların yetiştirildiği, eğitildiği ve savaşmalarını odak noktası olduğu sanal evcil hayvan topluluğu olarak ifade edilmektedir. Bu fantastik yaratıkların her birinin benzersiz genetik verileri Ethereum blok zincirinde depolanmaktadır. Dijital hayvanların her biri, yüzlerce olası vücut parçasından altısına sahip olabilir. Her vücut parçasının kendi savaş hareketleri de olduğundan benzersiz küçük savaş̧̧lar yaratma kombinasyonları sonsuz olarak gerçekleşmektedir (DappRadar, 2021).

\section{CryptoPunks}

Ethereum tabanlı oluşturulan 10,000 eşsiz koleksiyon kartı Amerikan stüdyosu Larva laboratuvarlarında yazılımcılar tarafından geliştirilmiştir ve NFT'lerin öncüsü olarak bilinmektedir. CryptoPunk'lar https://www.larvalabs.com/cryptopunks adresi üzerinden satın alınabilmektedir. 
Satın alma statüleri renklerine göre belirlenmektedir. Mavi fonlu olanları satışta olmadıklarını anlatırken kırmızı renkte olmaları satışlarının gerçekleşebileceğini göstermektedir (Kiong, 2021: 29-30)).

\section{SuperRare.co}

Her sanat eserinin, ağdaki bir sanatçı tarafından özgün bir şekilde oluşturulduğu SuperRare pazar yerinde benzersiz, tek baskilı dijital sanat eserleri toplanmakta ve takas edilmektedir (DappRadar, 2021).

\section{Rarible}

İlk NFT pazar yeridir. Topluluk tarafından desteklenen Rarible' de müzayede yapılmaktadır. Kodlama gerektirmeyen ve onaylı üreticilerin bulunduğu platformda birden fazla NFT yaratma işlemi yapılabilmektedir. Ayrıca ödül sistemi de mevcuttur RARI isimli yerel token bulunan Rarible 20 binden fazla yaratıcı ve koleksiyoner bulunmaktadır (DappRadar, 2021).

NFT'ler sanat pazar yerlerinde özellikle özgünlük ve kaynağının belirlenmesi sorununa çözüm sağlamaktadırlar. NFT akıllı bir sözleşmedir ve her akıllı sözleşmenin, bir blok zincir cüzdanı gibi kendi adresi bulunmaktadır. Ethereum tabanlı bir NFT'nin akıllı sözleşmesi 42 karakterlik bir Ethereum adresine sahiptir. İsteyen herkes bir blok gezginine girebilmekte, arama çubuğuna bir NFT'nin adresini yazarak NFT'nin akıllı sözleşmesini kolayca bulabilmektedir. Blok gezgini NFT'yi oluşturan adresi göstermektedir. Akıllı sözleşmenin adresinin sanatçının (veya bilinen diğer oluşturucunun) adresiyle eşleşmesi NFT'nin orijinalliğini göstermektedir. Eğer bu durum oluşmazsa NFT'nin orijinal ve sözde sanatçıya veya bilinen başka bir oluşturucuya ait olmadığı anlaşılmaktadır. Böylelikle Uzmanların onayına gereklilik ortadan kaldırılarak belirsizlik giderilmektedir. OpenSea gibi pazar yerlerinde, NFT'yi kimin oluşturduğu da doğrulanabilmektedir. Bir NFT'nin sayfasında, işlem geçmişi bölümüne gidilerek ve NFT'yi kimin oluşturduğunu görmek mümkün olmaktadır. Eğer bu, sanatçının (veya bilinen başka bir oluşturucunun) doğrulanmış adı veya adresi ise NFT gerçek olduğu anlaşılmaktadır. Bir diğer yandan fiziksel sanat eserlerinden farklı olarak NFT'ler eğer sahipleri onları yok etmek istemez ise sonsuza kadar bozulmadan kalabilmektedirler. NFT'lerin değerini arttıran önemli bir avantaj ise diğer kripto para birimleri gibi NFT'lerin de kopyalanamamasıdır. Bu kıtlık, dijital sanatçılar için NFT pazar yerlerine açılımı güçlendirmektedir (Fortnow ve Terry, 2021: 61-64).

\section{NFT kullanımları}

2021 sanat raporu verilerine göre 2013-2019 yılları arasında çevrimiçi sanat pazarındaki satışlar ikiye katlanarak 6 milyar dolar civarlarında gerçekleşmiştir. 2020'de ise işletmeler ve etkinlikler sınırlamalardan dolayı kapalı kaldığından çevrimiçi iletişim ve sergiler işletmelerin devamlılıkları için ön plana çıkmıştır. Geleneksel galeriler ve müzayede şirketleri yanı sıra sanat fuarları da çevrimiçi izleme odaları ve çeşitli platformlarla dijital seçenekler yelpazesini genişletmiştir. Bunun sonucunda da sanat ve antika satışları 2019'unun iki katına çıkarak 12,4 milyar dolara ulaşmıştır. Bu rakam çevrimiçi satışların 2019'da \%9 olan payının 2020'de \%25'e çıktığının da göstergesidir (McAndrew, 2021:212). Çevrimiçi ortamın rekabetçi ortamında sanatçılarda NFT'ler sayesinde çalışmalarını dijital formlara dönüştürmüşlerdir. Dijital sanat eserlerinin pazardaki her değişiminde sanatçının belirlemiş olduğu telif ücretini alacağı şekilde de programlanabilmektedir. Böylelikle dijital eserler de korunmuş olmaktadır. Ayrıca sanatçılar mülkiyeti ve içeriği aracılara devretmek zorunda kalmadıkları için de satışları ivme kazanır ve kar sağlarlar. Mad Dog Jones'un REPLICATOR'unun 4,1 milyon dolara satılması bunlara örnek olarak verilebilir (Wang vd., 2021:11). Mad Dog Jones olarak da bilinen Michah Dowbak'ın "REPLICATOR"'u Los Angeles şehir merkezindeki bir ofis alanına yerleştirilmiş bir fotokopi makinesinin zaman içindeki hikayesini anlatmaktadır (Resim: 1). Bu dijital görüntü aynı zamanda bir zamanların en son teknoloji olan bu makineye de gönderme yapmaktadır. Bir nevi nostaljik selam anlamındadır (Phillipp, 2021). Bir diğer örnek olarak da Beeple olarak bilinen dijital sanatçı Mike Winkelmann tarafından 69.346.250 dolara yaratılan “Everydays: The First 5000 Days" adlı sanat eseridir. Bu eser ile sanatçı yaşayan en değerli üç sanatçı arasında yer almaktadır (Quirion, 2021:11). Çalışma 21.069 x 21.069 piksel büyüklükten oluşan kare bir görüntü dosyasıdır (Resim: 2). Dijital bir mozaik olan çalışma Beeple'ın 1 Mayıs 2007'den beri günde bir kez web'de yayınladığı görüntülerden oluşmaktadır (Resim: 3). Bu “Gündelik" (Everdays)” serisi, Beeple'ın 3D grafiklerle oluşsa da bir eskiz defterinin dijital eşdeğeri olarak yorumlanabilir (News.artnet, 2021). 


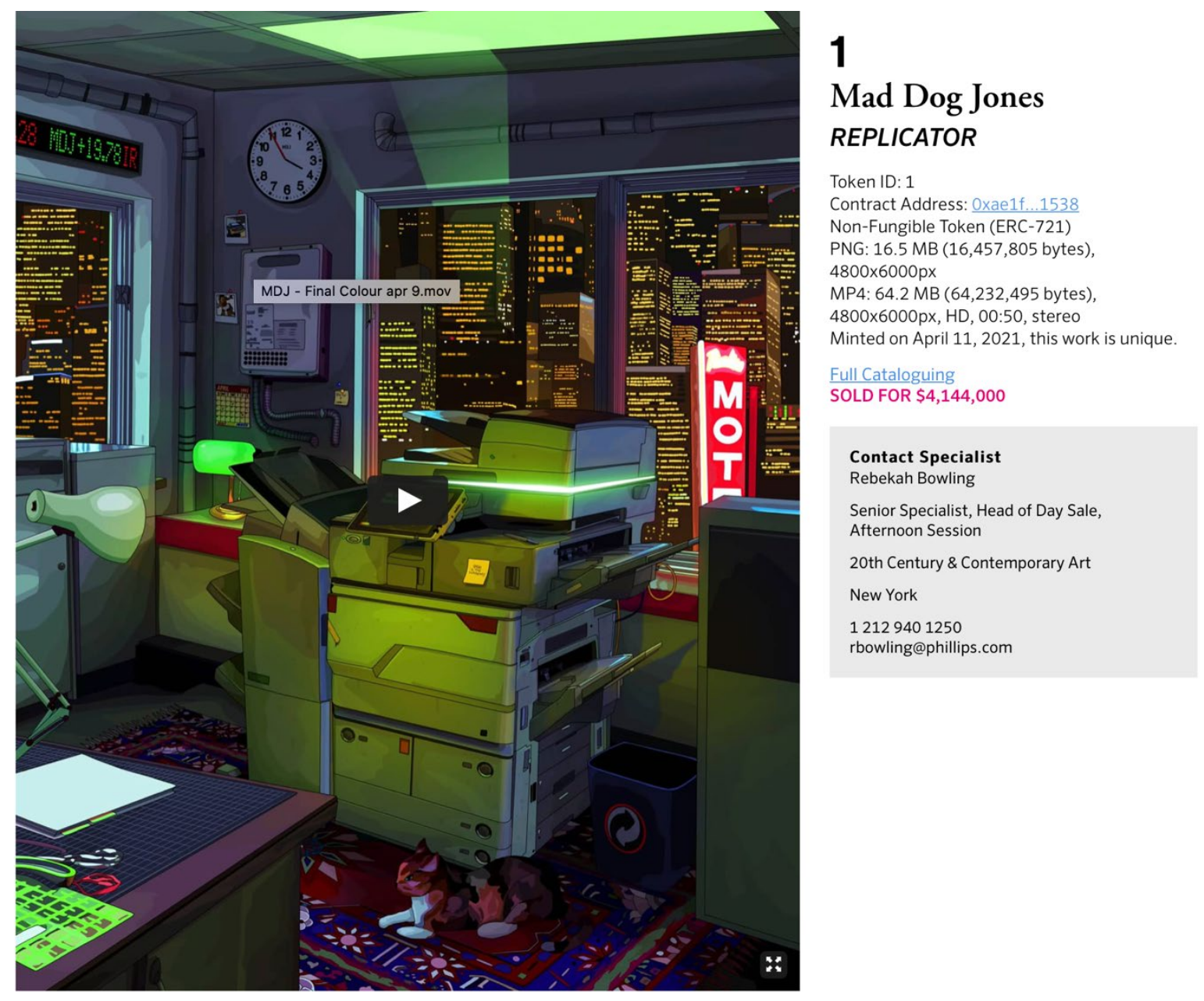

Resim 1. REPLICATOR (Phillips, 2021) 


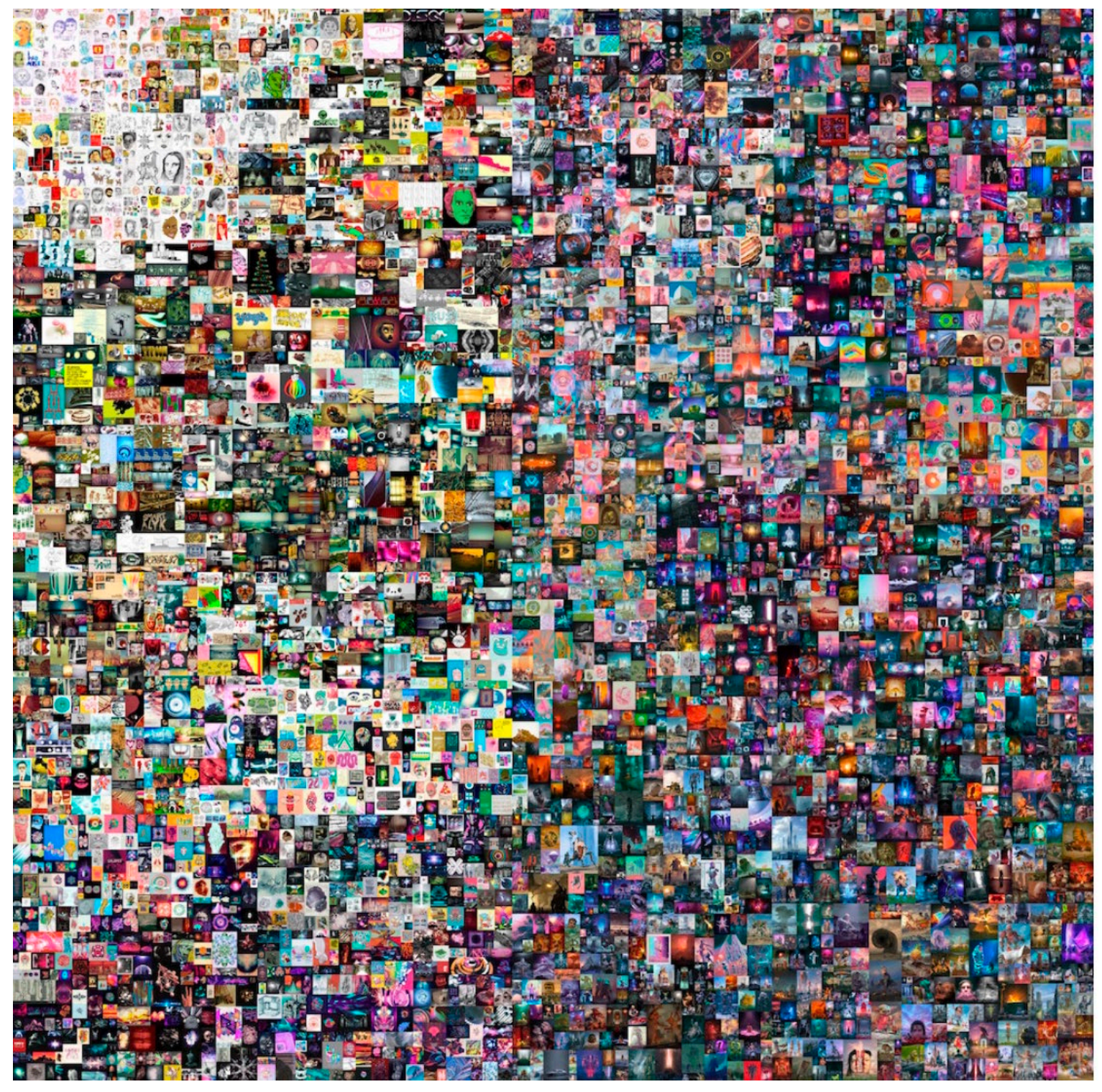

Resim 2. Everdays- The First Everdays (News.artnet, 2021).

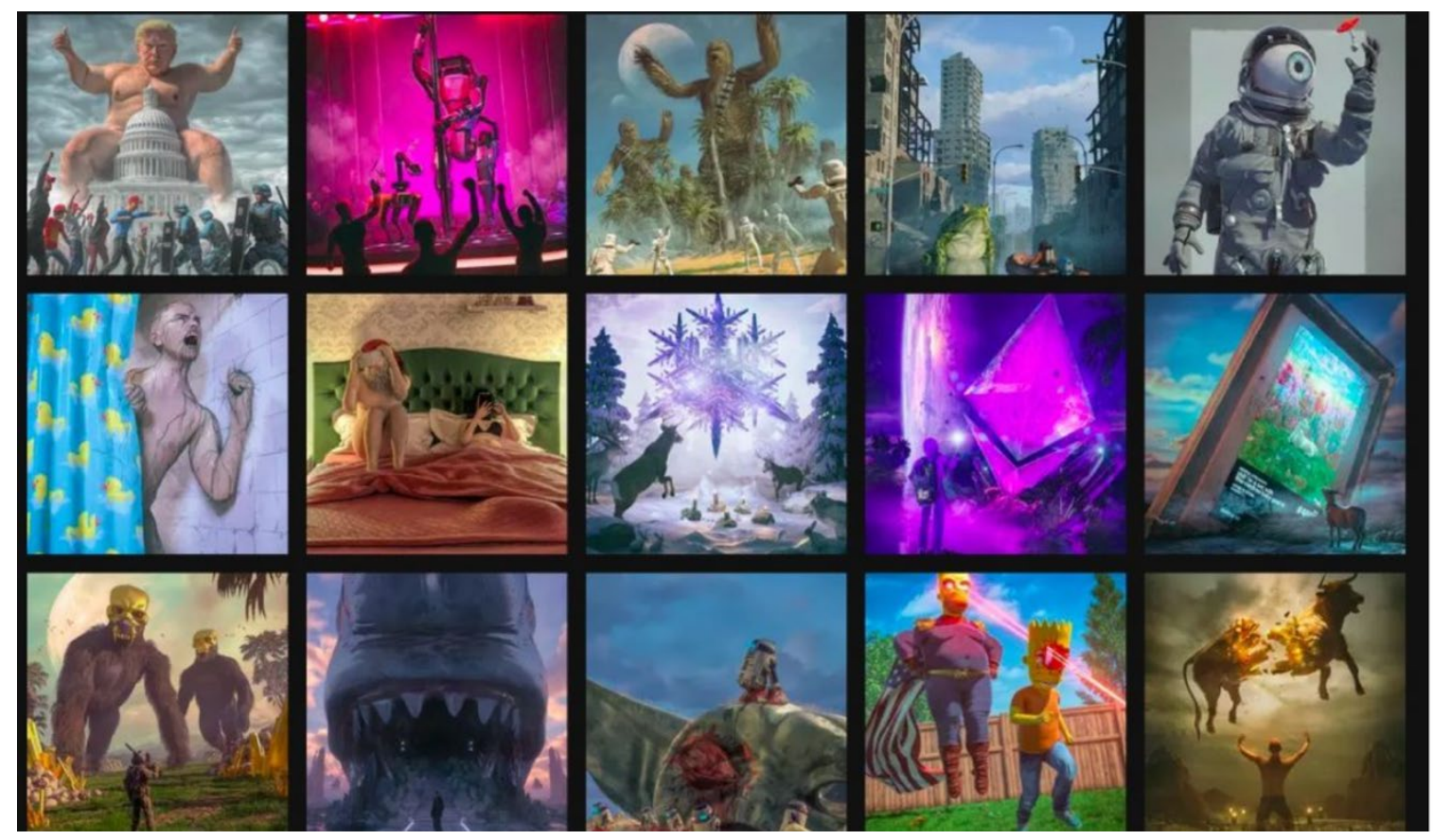

Resim 3: “Everdays" adlı eserin bazı parçalarının görüntüleri (News.artnet, 2021). 
Ülkemizde de pandemi, işsizlik ve ekonomik sıkıntılar sanatçıları NFT dünyası ile buluşturmuştur (Resim: 4). Marmara Üniversitesi grafik tasarım bölümü son sinıf öğrencisi olan "SadexKedu" adı ile bilinen ve Üsküdar Üniversitesi Görsel İletişim Tasarım bölümü mezunu “Lorento” adı ile bilinen sanatçılar bunlara örnektir (Koinbülteni, 2021).
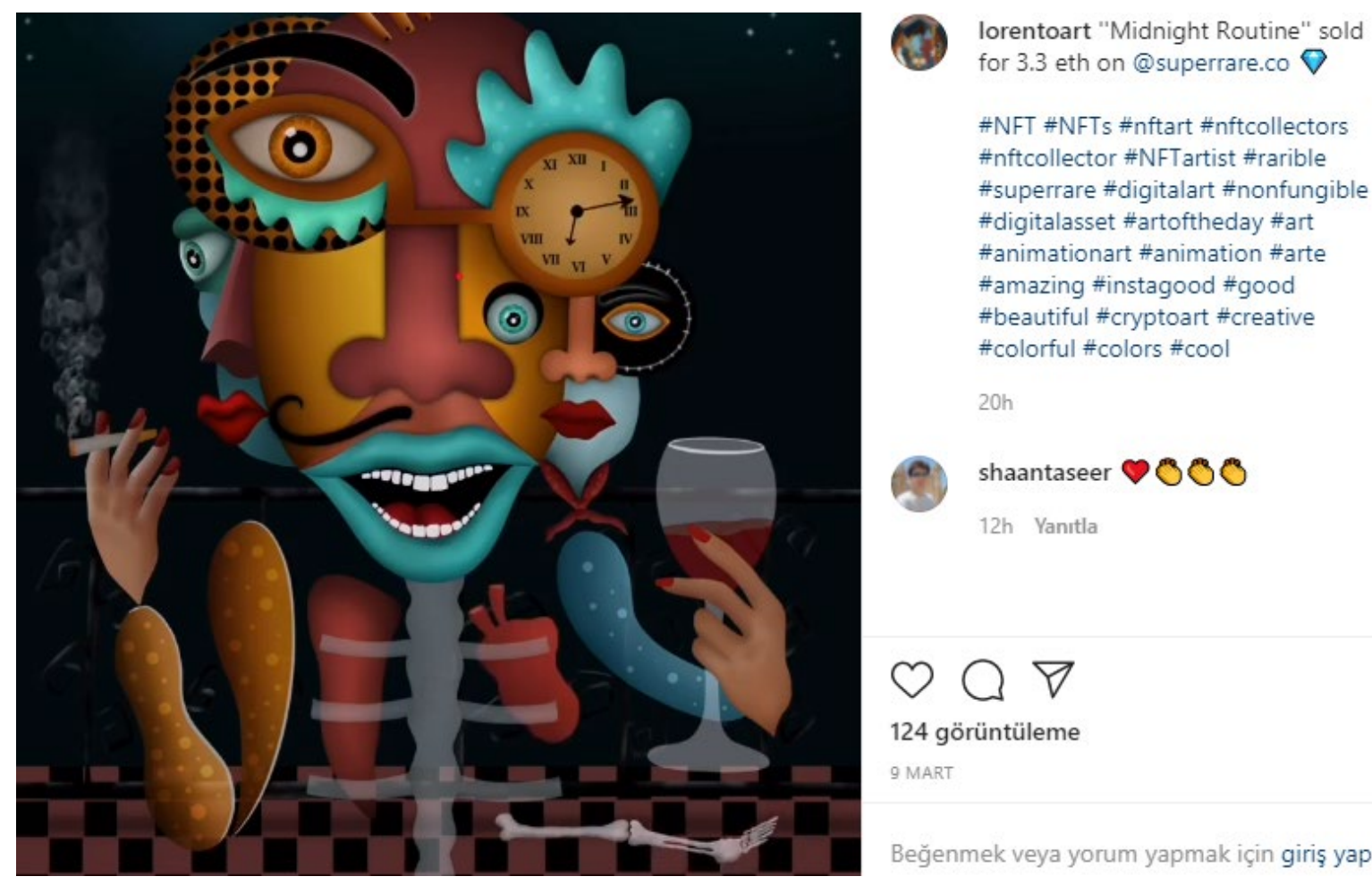

Resim 4: "Midnigt Routine" adlı eserin Sanatçısı "Lorento" tarafından oluşturulan görüntüsü (Koinbülteni, 2021).

\section{Değerlendirme ve sonuç}

Tolstoy'un sanat için ön gördüğü gelecek gerçekleşmekte; sanatın üst sınıfların sanatıyla ortak noktası kalmamakta insanlar arasında yaygınlaşıp kendi zamanınınkinden bambaşka temeller üzerinde inşa edilmektedir (Tolstoy, 2020:211). Aslında bu tespit yıllar öncesinden sınıfların, statülerin ve kalıpların eridiği akışkan moderniteye de işaret etmektedir.

Günümüzde internetin yükselişi ve küreselleşme gibi gelişmelerle sanat piyasaları, birbirine bağll, teknoloji odaklı ve eklektik hale gelmiştir. Küreselleşme ve dijitalleşme ile birlikte birçok sınır ortadan kalmış, birçok olgu gibi sanatta daha ulaşılabilir hale gelmiştir. Geçmişte sadece zengin ailelerin tekelinde olan sanat, herkesin rahatça dâhil olabildiği bir zemin kazanmıştır. Çin'in ve Ortadoğulu ülkelerin piyasaya girmesiyle pazar büyümüş, daha önemli hale gelmiştir. Sanat pazarı büyürken, pazara dâhil olan ortakların sayısı artmış, günümüzde üretilen sanat kalıpların dışında, tüketici kalıpların dışında, dolayısıyla satın alma biçimi de kalıpların dışındadır. Postmodern pazarlamada da ifade edilen etkileşimin çok yönlülüğü sanat pazarlarında da yaşanmaktadır. Değişen, kılık değiştiren (takma isimler) ve sanatını müşteri beklentilerine göre uyarlamayan satıcılar ve teknolojik bilgi sermayesine sahip olan müşteriler mevcuttur. Teknolojik bilgi ve zekanın sunulduğu deneyim ekonomisi sanal ortamlarda yaşanmaktadır. Alıcı ve satıcı dengelerinin NFT sistemiyle dijital temellerinin sağlam atıldığı sistemde pazarlamanın değiş ve tokuşu "şifrelerin" aracı olduğu ortamlara dönüşmektedir. Bir anlamda yapay aracılar (şifreler) "pazar yerlerinin" yeni aktörleri olarak görülebilir.

Değişime dahil olan her iki tarafında kazandığı bu ortamda yeniye odaklanmanın önemi oldukça önemli görülmektedir. Ressamin dijital tuvalinde ya da dijital eskiz defterinde pazarlama ön plana çıkmaktadır ve dijital yansımaların iletişimi için önemli bir görevi üstlenmektedir. İletişim, iş birliği ve yaratım hem güvende hem de özgür olmak istemektedir. NFT'lerin temellerini oluşturan sistem merkeziyetçilikten uzak ama şeffaf ve hakların önemine sahip çıkmaktadır. Değerler sanal kayıtlardadır ve dijital mülkiyet sertifikası sonsuz algoritmalar içinde saklanmaktadır. Ayrıca bütünle birlikte bütünün parçası da önemlidir. Bu niceliksel büyüklükler ziyade anlamlara odaklanılması olarak da yorumlanabilir. Anlamlar evrensel olmasa da sahipliğin kanıtlanması önemli görülmektedir. NFT 
sistemi sahip olma isteğinin güçlü olduğu ama sahip olma sonrası kazanılanların daha adil olduğu bir sistem olarak yorumlanabilir. Alıcıların ön planda olduğu sistemlerden uzaklaşılarak sanat satıcılarının özgürleştiği, kalıplarından sıyrıldıkları, estetik kaygıdan uzak ve telif haklarına daha güçlü sahip olarak çıktıkları kazançlarında ivme kazandıkları görülmektedir.

Değişen pazar yeri ve NFT'ler; alıcıların satıcıya direkt ulaşabilmesi, ürüne erişimin kolay olması, tanıtımın kolay ve ucuz olması, taraftarlarına telif hakkı ve dijital mülkiyet kolaylığı sağlaması, istenilen yerde istenilen zamanda erişilme olanağı sağlaması gibi pazarlamanın temel fayda amaçlarıyla örtüşmektedir. Bu nedenle bu alanda pazarlama ile ilgili yapılacak her çalışma büyük öneme sahiptir. Sürekli yenilenerek gelişen bu mecrada var olabilmek için sanat pazarlamasıyla ilgili nitel ve nicel çalışmalarla konu derinleştirilebilir.

\section{Hakem Değerlendirmesi / Peer-review:}

Dış bağımsız

Externally peer-reviewed

\section{Çıkar Çatışması / Conflict of interests:}

Yazar(lar) çıkar çatışması bildirmemiştir.

The author(s) has (have) no conflict of interest to declare.

\section{Finansal Destek / Grant Support:}

Yazar(lar) bu çalışma için finansal destek almadığını beyan etmiştir.

The author(s) declared that this study has received no financial support.

\section{Yazar Katkıları / Author Contributions:}

Fikir/Kavram/Tasarım - Idea/Concept/Design: E.P.S., S.F. Veri Toplama ve/veya İşleme - Data Collection and/or Processing: E.P.S., S.F. Analiz ve/veya Yorum - Analysis and/or Interpretation: E.P.S., S.F. Kaynak Taramas1 - Literature Review: E.P.S., S.F. Makalenin Yazımı - Writing the Article: E.P.S., S.F. Eleştirel İnceleme - Critical Review: E.P.S., S.F., Onay - Approval: E.P.S., S.F.

\section{Kaynakça / References}

Academy.binance, (2021), https://academy.binance.com/tr/articles/a-guide-to-crypto-collectiblesand-non-fungible-tokens-nfts Erişim tarihi: 1.06.2021

Bagozzi, R. P. (1978). Marketing as exchange: a theory of transactions in the marketplace. American Behavioral Scientist, 21(4), 535-556.

Bauman. Z. (2011). Akışkan Modern Dünyadan 44 Mektup, (Çev. Pelin Siral), İstanbul: Habitus Yayincilik.

Barimeks, (2021),https:// www.barimeks.com/sss/hash-orani-nedir Erişim tarihi: 2.06.2021

Bayrak, B. (2013) Beykent Üniversitesi Sosyal Bilimler Dergisi/Journal Ofsocial Sciences (6), 1, 123-137.

Bourriaud, N., (2004). Postprodüksiyon, Nermin Saybaşılı (çev.), Bağlam Yayınları, İstanbul.

Beteş, F. Medeniyet Sanat, İMÜ Sanat, Tasarım ve Mimarlık Fakültesi Dergisi, Cilt:2, Sayı:1, 2016, s. 926

Bozoğlu Demirdöven, J., ve Ödekan, A. (2009). Müzayedelerin sanat piyasalarındaki rolü ve Türkiye'deki yansımaları. İTÜ Dergisi̇/b, 5(1), 55-66

Butler, P. (2000): By Popular Demand: Marketing the Arts, Journal of Marketing Management, 16:4, 343364 
Cachin, C., \& Vukolić, M. (2017). Blockchain consensus protocols in the wild. arXiv preprint arXiv:1707.01873.

Cemalcılar, İ. Pazarlama Nedir? Eskişehir İktisadi ve Ticari İlimler Akademisi Dergisi, 1(2), 63-72.

Cebrailoğlu, O. (2009) Ahmet Keleşoğlu Eğitim Fakültesi Dergisi Sayı 28, Sayfa 241 -251

Çalıkoğlu, L. (2005), Çağdaş sanat Konuşmaları. İstanbul: Yapı Kredi Yayınları

Çildir, Ç. ve Fettahlığlu, H. S. (2019). Sanat Ve Pazarlama İlişkisi. Kahramanmaraş Sütçü İmam Üniversitesi İktisadi ve İdari Bilimler Fakültesi Dergisi, 9 (2) , 47-61. Retrieved from http://iibfdergisi.ksu.edu.tr/tr/pub/issue/51188/657150

DappRadar, (2021), https://dappradar.com/ethereum/marketplaces/axie-marketplace Erişim Tarihi: 30.08.2021

Dowling, M. (2021). Is non-fungible token pricing driven by cryptocurrencies? Finance Research Letters, 102097.

Eckhardt, G. M., ve Bardhi, F. (2020). New dynamics of social status and distinction. Marketing Theory, 20(1), 85-102.

Evrimagaci,(2021),https:/ / evrimagaci.org/nft-nonfungible-token-nedir-insanlar-kolaycakopyalanabilen-dijital-urunlere-neden-milyonlarca-dolar-oduyorlar-10296 Erişim tarihi: 1.06.2021

Fındıklı, S. (2021). Kripto Paranın Aile İşletmeleri Üzerindeki Etkisi. In O. Yılmaz \& Ö. Çark (Eds.), Aile İşletmelerinde Dijital Teknojiler (pp. 299-317). Nobel Yayıncılık.

Fortnow, M. ve Terry, Q. (2021). The NFT Handbook How to Create, Sell and Buy Non-Fungible Tokens, published John Wiley \& Sons, Hoboben, New Jersey.

Hexaresearch, (2021), https://www.hexaresearch.com/research-report/us-online-art-sculpturemarket.html Erişim tarihi: 31.07.2021

Kerrigan, F., O'Reilly, D., ve vom Lehn, D. (2009). Producing and consuming arts: A marketing perspective. Consumption Markets \& Culture, 12(3), 203-207. https://doi.org/10.1080/10253860903063212

Kiong, L. V. (2021). DeFi, NFT and GameFi Made Easy: A Beginner's Guide to Understanding and Investing in DeFi, NFT and GameFi Projects. Liew Voon Kiong.

Koinbülteni, (2021),https:/ / koinbulteni.com/iste-en-buyuk-5-nft-platformu-95435.html

https://koinbulteni.com/olumsuz-sartlar-bu-iki-sanatciyi-nft-ile-bulusturdu-96058.html Erişim tarihi: 31.07.2021

Kotler, P., ve Levy, S. J. (1969). Broadening the concept of marketing. Journal of marketing, 33(1), 10-15.

Lee, H. (2005). When Arts Met Marketing Arts Marketing Theory Embedded In Romanticism. International Journal of Cultural Policy, 11(3), 289-305.

Lee, Jin Woo and Lee, Soo Hee (2017) Marketing from the Art World: A Critical Review of American Research in Arts Marketing. The Journal of Arts Management, Law, and Society, 47 (1). pp. 17-33. ISSN 1063-2921.

Phillips, (2021), https://www.phillips.com/mdj Erişim tarihi: 15.08.2021

Rfrncr.io, (2021), https://rfrnce.io/nft-nedir/ Erişim tarihi: 15.08.2021

Şahin, F. ve Söylemez, C. (2021). Güdülenmiş Tüketici Yenilikçiliğinin Dijital Medya Platformlarının Algılanan Tüketici Temelli Marka Değeri ve Marka Tutumu Üzerine Etkisi: Covid-19 Döneminde Netflix Üzerine Bir İnceleme, Erciyes Üniversitesi İktisadi ve İdari Bilimler Fakültesi Dergisi, Say1:58, ss.302-331.

Thompson, D. (2011). Sanat Mezat. İletişim Yayınları. (Çev. Renan Akman)

MacFarlane, A. (2015). Marcel Duchamp (1887-1968). Philosophy Now, 108, 9-10.

McAndrew, C. 2021. The Art Market 2021. Basel: Art Basel and UBS, Zurich: Art Basel and UBS.

McGregor. J.H.S (2021). Tarihöncesinden Bugüne Akdeniz Dünyası ve Doğa, (Çev. Barış Gönülşen), İstanbul: Türkiye İş Bankası Kültür Yayınları 
Merriam-webster, (2021) https://www.merriam-webster.com/dictionary/fungible Erişim tarihi: 1.06.2021

Musan, D. I., William, J. ve Gervais, A. (2020). NFT. finance Leveraging Non-Fungible Tokens.

News.artnet, ( 2021), https://news.artnet.com/opinion/beeple-everydays-review-1951656 Erişim tarihi: 3.09 .2021

Quirion, A. (2021). What Is an NFT and Why Should Archivists Pay Attention? archeota, 11.

Slater, A. (2007). 'Escaping to the gallery': understanding the motivations of visitors to galleries. International Journal of Nonprofit and Voluntary Sector Marketing, 12(2), 149-162. https://doi.org/10.1002/nvsm.282

Stallabrass, J. (2020). Contemporary art: a very short introduction (Vol. 146). Oxford University Press, USA.

Tolstoy, L. N. (2020). Sanat Nedir? (M. Beyhan (trans.); 12th ed.). Türkiye İş Bankası Kültür Yayınları.

Velthuis, O. (2005). Symbolic Meanings of Prices on the Market for Contemporary Art, , Princeton University Press

Wang, Q., Li, R., Wang, Q., ve Chen, S. (2021). Non-Fungible Token (NFT): Overview, Evaluation, Opportunities and Challenges. arXiv preprint arXiv:2105.07447.

Webrazzi, (2021), https://webrazzi.com/2021/03/03/nft-nedir/ Erişim tarihi: 1.06.2021 